Article

\title{
Potential Nutraceutical Benefits of In Vivo Grown Saffron (Crocus sativus L.) As Analgesic, Anti-inflammatory, Anticoagulant, and Antidepressant in Mice
}

\author{
Asif Khan ${ }^{1}$, Nur Airina Muhamad 1,*, Hammad Ismail ${ }^{2}$ (D), Abdul Nasir ${ }^{3}$ (D), \\ Atif Ali Khan Khalil ${ }^{4}$ (D), Yasir Anwar ${ }^{5}$ (D), Zahid Khan ${ }^{6}$, Amjad Ali ${ }^{7}$, Rosna Mat Taha ${ }^{1}$, \\ Baker Al-Shara ${ }^{1}$ (D) , Sara Latif ${ }^{8}$, Bushra Mirza ${ }^{8,9}$ (D), Yousef Abdal Jalil Fadladdin ${ }^{5}$, \\ Isam Mohamed Abu Zeid ${ }^{5}$ and Saed Ayidh Al-Thobaiti ${ }^{10}$ \\ 1 Institute of Biological Sciences, Faculty of Science, University of Malaya, 50603 Kuala Lumpur, Malaysia; \\ asif.khan.qau@gmail.com (A.K.); rosnataha2020@gmail.com (R.M.T.); Bakearbio@yahoo.com (B.A.-S.) \\ 2 Department of Biochemistry and Biotechnology, University of Gujrat, Gujrat 50700, Pakistan; \\ hammad.ismail@uog.edu.pk \\ 3 Department of Molecular Science and Technology, Ajou University, Suwan 16499, Korea; \\ anasirqau@gmail.com \\ 4 Department of Biological Sciences, National University of Medical Sciences, Rawalpindi 46000, Pakistan; \\ Atif.ali@numspak.edu.pk \\ 5 Department of Biological Sciences, Faculty of Science, King Abdulaziz University, P.O. Box 54229, Jeddah, \\ Saudi Arabia; yanwarulhaq@kau.edu.sa (Y.A.); yfadladdin@kau.edu.sa (Y.A.J.F.); \\ abuzeidmm@yahoo.com (I.M.A.Z.) \\ 6 Department of Pharmacognosy, Faculty of Pharmacy, Federal Urdu University of Arts Science \\ and Technology, Karachi 75300, Pakistan; zahidkhan@fuuast.edu.pk \\ 7 Department of Botany, University of Malakand, Khyber Pakhtunkhwa 18800, Pakistan; \\ amjad1990.aa48@gmail.com \\ 8 Department of Biochemistry, Quaid-i-Azam University, Islamabad 45320, Pakistan; \\ saralatifawan@gmail.com (S.L.); bushramirza@qau.edu.pk (B.M.) \\ 9 Lahore College for Women University, Lahore 54000, Pakistan \\ 10 Department of Biology, University College Turabah, Taif University, Taif 21995, Saudi Arabia; saed@tu.edu.sa \\ * Correspondence: nurairina@um.edu.my
}

Received: 24 September 2020; Accepted: 20 October 2020; Published: 22 October 2020

check for updates

\begin{abstract}
Crocus sativus, a medicinally important herbaceous plant, has been traditionally used to cure coughs, colds, insomnia, cramps, asthma, and pain. Moreover, the therapeutic applications of saffron include its immunomodulatory and anticancer properties. The current experimental analysis was performed to explore the potential nutraceutical efficacy of corm, leaf, petal, and stigma of saffron ethanolic extracts as analgesic, anti-inflammatory, anticoagulant, and antidepressant using hot plate, carrageenan-induced paw edema, capillary tube and forced swim test, respectively in mice. The results indicated that among all the extracts, stigma ethanolic extract (SEE) represented maximum latency activity $(72.85 \%)$ and edema inhibition $(77.33 \%)$ followed by petal ethanolic extract (PEE) with latency activity and edema inhibition of 64.06 and $70.50 \%$, respectively. Corm ethanolic extract (CEE) and leaf ethanolic extract (LEE) displayed mild analgesic activity of $22.40 \%$ and $29.07 \%$, respectively. Additionally, LEE (53.29\%) and CEE (47.47\%) exhibited mild to moderate response against inflammation. The coagulation time of SEE (101.66 s) was almost equivalent to the standard drug, aspirin (101.66 s), suggesting a strong anticoagulant effect followed by PEE (86.5 s). LEE (66.83 s) represented moderate inhibitory effect on coagulation activity while CEE (42.83 s) showed neutral effect. Additionally, PEE and SEE also expressed itself as potential antidepressants with immobility time $\leq 76.66 \mathrm{~s}$, while CEE (96.50 s) and LEE (106.83 s) indicated moderate to mild antidepressant
\end{abstract}


efficacy. Based on the in vivo activities, saffron extract, particularly SEE and PEE, can be used as a potential nutraceutical and therapeutic agent due to its significant pharmacological activities.

Keywords: Crocus sativus; in vivo; carrageenan; analgesic; antidepressant; anticoagulant

\section{Introduction}

In recent times, traditional medicinal plants are gaining much attention in pharmaceutical industries and served as a part of the primary medical emergencies in the treatment of numerous diseases. Crocus sativus, or saffron, is one such stemless herbaceous plant grown as a source of its spice for nearly 3600 years and belongs to the family Iridaceae. Saffron is geographically distributed in Irano-Touranian regions, East Asia, and Mediterranean climates and largely cultivated in countries like Iran, Afghanistan, India, France, Turkey, Italy, Spain, and Morocco [1]. Current estimates for total world annual production of saffron are $418 \mathrm{t}$ per year [2]. Iran, the world's largest producer of saffron with around 90,000 ha harvest area and $336 \mathrm{t}$ annual yield, is said to produce more than $90 \%$ of the total saffron produced worldwide [3].

Saffron plant comprises of the corm, foliar structure, and floral organs as the main parts (Figure 1). Commercially, saffron is a dietary spice obtained from three red pungent stigmatic lobes of the Crocus sativus flower. According to an estimate, it takes around 60,000 Crocus flowers to produce just $1 \mathrm{~kg}$ of this unique spice, which equates to 370 to $470 \mathrm{~h}$ of work [4] and needs a cultivation area of approximately $2000 \mathrm{~m}^{2}$ [5]. At a retail price of almost US\$1000-10,000 per $\mathrm{kg}$, saffron is considered the costliest spice of the world [6]. Saffron stigma contains more than 150 phytochemical ingredients, belonging to various divisions of secondary metabolites such as carotenoids, flavonoids, terpenoids, and anthocyanin. Amongst the 50 constituents identified so far, apocarotenoids, including crocin, crocetin, picrocrocin, and safranal, emerge as the major constituents of saffron stigma, primarily responsible for imparting a distinct colorant, flavor, and aroma to the spice [7]. These compounds are derived from lipophilic carotenoid, zeaxanthin by oxidative cleavage. Moreover, a series of flavonoids (all glycosidic derivatives of kaempferol) have also been characterized in the stigma and petals of saffron, which, together with picrocrocin, give the characteristic bitter feature to this spice [8]. Furthermore, some anthraquinones and anthocyanin secondary components are also reported to be extracted from corms and petals of saffron [9].

Conventionally, saffron has a long history of being used as a spice and food additive [10]. Besides its use in culinary [11] and cosmetic preparation [12], saffron has been used as a folk remedy for coughs, colds, insomnia, cramps, asthma and bronchospasms, liver disease, pain, and epilepsy [2]. Saffron tea has been reputed to be a potential complementary treatment for psoriasis in medical nutrition therapy [13]. Many pharmacological studies have shown that this plant and its phytochemicals have emerged as nutraceutical elements, endowed with beneficial effects on health showing antibacterial [14], antioxidant, cytotoxic [15,16], antifungal [17], immunomodulatory [18,19], anti-mutagenic [20], aphrodisiac [21], antitussives [22,23], and antiplatelet effects [24]. Traditional and modern biomedical reports have also proved saffron to cure coronary artery diseases [25], respiratory diseases [26], menstrual disorders [27,28], and neurodegenerative disorders [29]. All these desirable properties of saffron have been attributed to the stigmas, whereas other parts of the plant have been much less studied. Nevertheless, a large quantity of saffron by-products is produced during the stigmatization process with little commercial value but thrown away after harvesting. According to an estimate, approximately $1500 \mathrm{~kg}$ of leaves, $350 \mathrm{~kg}$ of petals, and several hundred cormlets too small for cultivation or biologically and physically damaged to be regrown are rejected to get spice of only 1 $\mathrm{kg}$ [30]. However, this biomass contains a multitude of phytochemical ingredients whose exploitation would significantly enhance the sustainability and profitability of saffron yield. These saffron based by-products need to be tested to assess its pharmacological applications. 


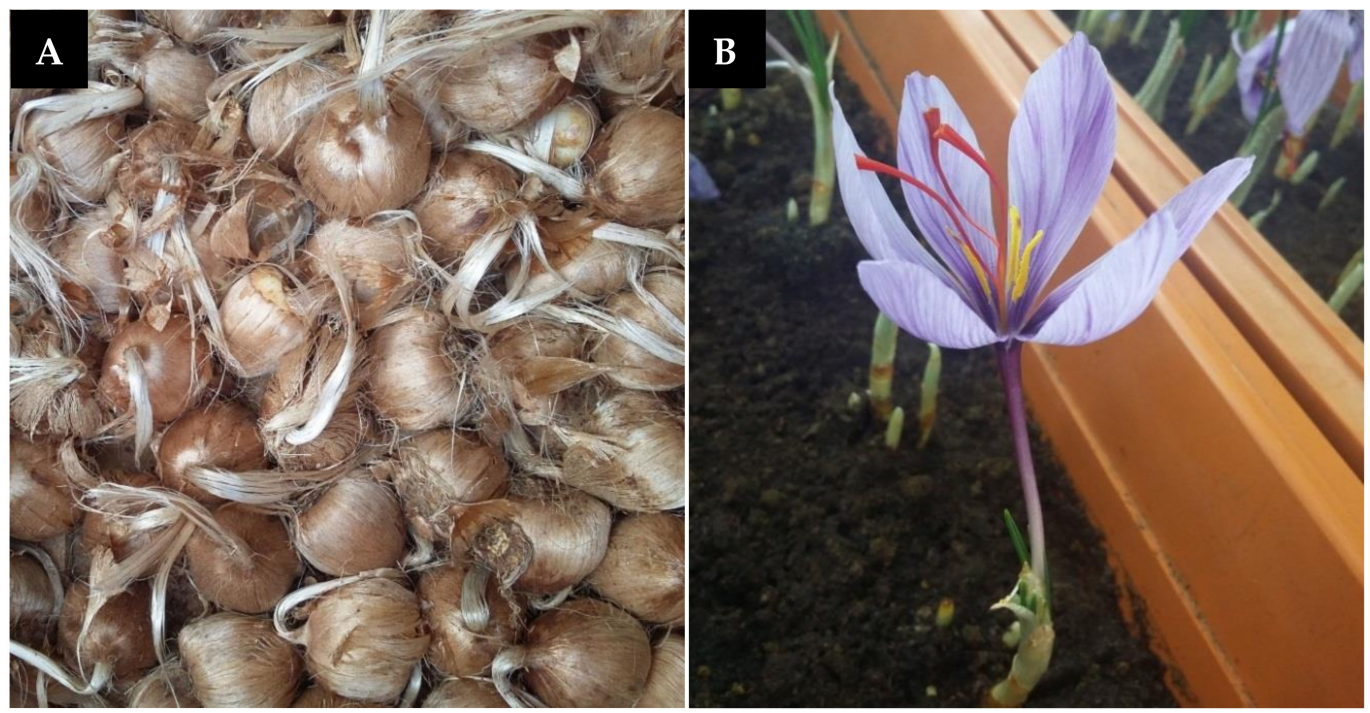

Figure 1. Main components of saffron (Crocus sativus), (A) corms (B) flower.

Bioactive compounds from petals have shown antinociceptive, anti-inflammatory [31], cytotoxic, antimicrobial, antioxidant, antidiabetic [32], antiobesity [33], antidepressant [34], anticancer, antityrosinase properties, as well as reduce blood pressure and contractility [35]. Several phenolic compounds from saffron leaves have been identified, showing antibacterial [36,37], anticancer [30], antioxidant, and metal ion chelating activities $[37,38]$. Likewise, bioactive constituents in saffron corm, such as proteoglycans, revealed to have a cytolytic effect on human tumor and plant cells and triterpenoid saponins on fungicidal and anticancer activities [30]. Polyphenols showing antibacterial, radical scavenging activity [39,40], and a mannan-binding lectin [41] have also been investigated in saffron corms. The existing experimental analysis aimed to explore the anti-inflammatory, analgesic, anticoagulant, and antidepressant potentials of various extracts of Crocus sativus L. in mice by carrageenan-induced paw edema test, hot plate assay, capillary method, and forced swim test, respectively. Up to now, ethanolic extracts of stigma, petals, corms, and leaves of in vivo cultivated saffron have not been previously studied for their nutraceutical properties against analgesia, inflammation, coagulation, and depression.

\section{Results}

\subsection{Acute Toxicity Study}

During the 7-days study, none of the orally administered saffron ethanolic extracts showed any mortality in the animals treated with $800 \mathrm{mg} / \mathrm{kg}$. Furthermore, tested samples did not produce any notable behavioral changes in mice during the observation period.

\subsection{Hot Plate Analgesic Test}

The test is based on the use of thermal stimuli to determine the effect of analgesics. For this purpose, an easy and cost-effective method, the hot plate analgesic test, was performed. Results of saffron ethanolic extracts presented in the form of latency time indicated that all the extracts showed significant $(p<0.05)$ analgesic effect in a time-dependent manner (Table 1). Aspirin, used as a reference drug, showed the highest latency $(17.51 \pm 0.50)$ at $1 \mathrm{~h}$ followed by reduction $(16.82 \pm 0.45)$ at $2 \mathrm{~h}$. Among all the extracts of saffron tested, stigma ethanolic extract (SEE) showed the highest latency activity $(7.80 \pm 0.16,11.30 \pm 0.21,12.80 \pm 0.33$, and $13.50 \pm 0.28)$ at $0,0.5,1$, and $2 \mathrm{~h}$, respectively. On the other hand, leaf ethanolic extract (LEE) exhibited no significant difference at $0 \mathrm{~h}$ when compared with negative control (saline) but showed the least activity of $5.92 \pm 0.14,6.22 \pm 0.15$, and $6.65 \pm 0.19$ at $0.5,1$, and $2 \mathrm{~h}$, respectively. Based on the percent inhibition (Figure 2), SEE was more prominent in 
reducing analgesia $(44.91 \%, 63.89 \%$, and $72.85 \%)$, followed by petal ethanolic extract (PEE), showing $38.84 \%, 53.07 \%$, and $64.06 \%$ inhibition at $0.5,1$, and $2 \mathrm{~h}$, respectively. Furthermore, corm ethanolic extract (CEE) and LEE responded poorly and showed weak analgesic activity of $22.40 \%$ and $29.07 \%$ at $2 \mathrm{~h}$, respectively.

Table 1. Latency time of $C$. sativus ethanolic extracts in hot plate assay.

\begin{tabular}{cccccc}
\hline \multirow{2}{*}{ Group } & Dose $(\mathbf{m g} / \mathbf{k g})$ & \multicolumn{4}{c}{ Latency Time (s) } \\
\cline { 3 - 6 } & & $\mathbf{0 ~ h}$ & $\mathbf{0 . 5} \mathbf{~ h}$ & $\mathbf{1} \mathbf{~ h}$ & $\mathbf{2 ~ h}$ \\
\hline Saline & $1 \mathrm{~mL} / \mathrm{kg}$ & $4.70 \pm 0.06$ & $5.00 \pm 0.02$ & $5.50 \pm 0.01$ & $5.40 \pm 0.04$ \\
Aspirin & 10 & $9.45 \pm 0.28^{* * *}$ & $16.38 \pm 0.42^{* * *}$ & $17.51 \pm 0.50^{* * *}$ & $16.82 \pm 0.45^{* * *}$ \\
CEE & 800 & $6.20 \pm 0.17^{* * *}$ & $6.93 \pm 0.16^{* * *}$ & $7.15 \pm 0.13^{* * *}$ & $7.58 \pm 0.14^{* * *}$ \\
LEE & 800 & $5.15 \pm 0.15$ & $5.92 \pm 0.14^{* *}$ & $6.22 \pm 0.15^{*}$ & $6.65 \pm 0.19^{* *}$ \\
SEE & 800 & $7.80 \pm 0.16^{* * *}$ & $11.30 \pm 0.21^{* * *}$ & $12.80 \pm 0.33^{* * *}$ & $13.50 \pm 0.28^{* * *}$ \\
PEE & 800 & $6.78 \pm 0.17^{* * *}$ & $9.42 \pm 0.24^{* * *}$ & $10.38 \pm 0.29^{* * *}$ & $11.13 \pm 0.35^{* * *}$ \\
\hline
\end{tabular}

Each value is represented as mean \pm S.D. Where, ${ }^{*} p<0.05,{ }^{* *} p<0.01,{ }^{* * *} p<0.001$ statistically significant relative to control (saline).

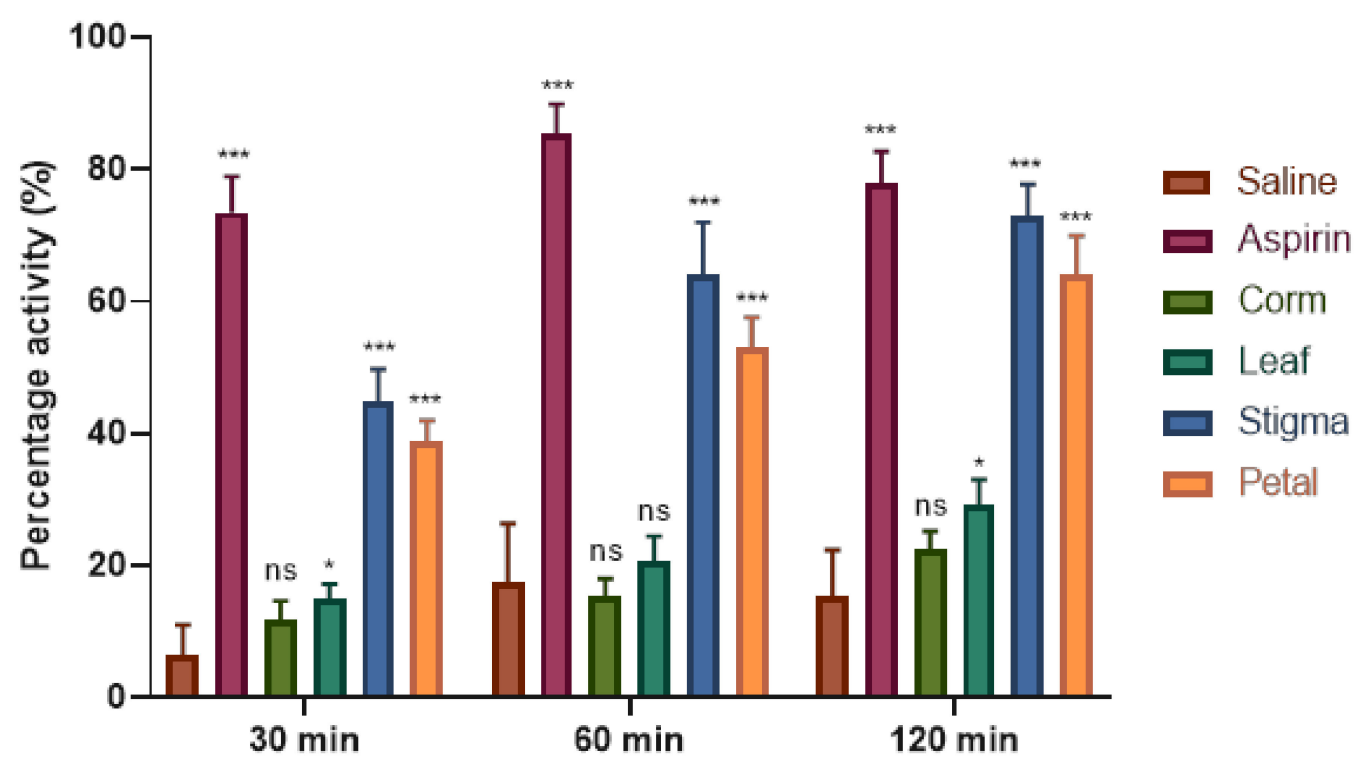

Figure 2. Percentage analgesia of C. sativus ethanolic extracts at selected time period in mice. Each value is represented as mean \pm S.D. Where, ${ }^{*} p<0.05,{ }^{* *} p<0.01,{ }^{* * *} p<0.001$ statistically significant relative to control (saline).

\subsection{Carrageenan-induced Hind Paw Edema Test}

The anti-inflammatory effects of saffron ethanolic extracts was investigated by the mouse paw-edema test, and the findings are presented in Table 2. Sub planter injection of carrageenan gradually increased edema paw volume of the saline-treated animals. However, as a positive control, diclofenac potassium attenuated paw edema volume by $88.87 \%$, as depicted in Figure 3. Moreover, oral administration of saffron ethanolic extracts showed a significant $(p<0.05)$ decrease in edematous paw volume in a time-dependent manner. SEE $(800 \mathrm{mg} / \mathrm{kg})$ produced an anti-inflammatory activity $1 \mathrm{~h}$ after administration and continued until the end of the experimentation, with the most prominent inhibition of $77.33 \%$ followed by PEE (70.50\%) at the fourth $h$ of the study. LEE and CEE exhibited moderate but significant $(p<0.05)$ potential with the percentage edema inhibition of $53.29 \%$ and $47.47 \%$, respectively. 
Table 2. Anti-inflammatory effect of $C$. sativus ethanolic extracts.

\begin{tabular}{cccccc}
\hline \multirow{2}{*}{ Group } & \multirow{2}{*}{ Dose $(\mathbf{m g} / \mathbf{k g})$} & \multicolumn{4}{c}{ Mean Edema Volume $(\mathbf{m L})$} \\
\cline { 3 - 6 } & & $\mathbf{1 ~ h}$ & $\mathbf{2} \mathbf{~ h}$ & $\mathbf{3 ~ h}$ & $\mathbf{4} \mathbf{~ h}$ \\
\hline Saline & $1 \mathrm{~mL} / \mathrm{kg}$ & $0.47 \pm 0.03$ & $0.56 \pm 0.03$ & $0.69 \pm 0.04$ & $0.76 \pm 0.03$ \\
Diclofenac potassium & 10 & $0.25 \pm 0.02^{* * *}$ & $0.17 \pm 0.01^{* * *}$ & $0.08 \pm 0.01^{* * *}$ & $0.04 \pm 0.01^{* * *}$ \\
CEE & 800 & $0.43 \pm 0.03$ & $0.37 \pm 0.03^{* * *}$ & $0.30 \pm 0.01^{* * *}$ & $0.25 \pm 0.03^{* * *}$ \\
LEE & 800 & $0.37 \pm 0.03^{* *}$ & $0.31 \pm 0.02^{* * *}$ & $0.26 \pm 0.01^{* * *}$ & $0.20 \pm 0.03^{* * *}$ \\
SEE & 800 & $0.26 \pm 0.01^{* * *}$ & $0.19 \pm 0.02^{* * *}$ & $0.14 \pm 0.01^{* * *}$ & $0.07 \pm 0.01^{* * *}$ \\
PEE & 800 & $0.29 \pm 0.02^{* * *}$ & $0.23 \pm 0.02^{* * *}$ & $0.17 \pm 0.01^{* * *}$ & $0.11 \pm 0.01^{* * *}$ \\
\hline
\end{tabular}

Each value is represented as mean \pm S.D. Where, ${ }^{*} p<0.05,{ }^{* *} p<0.01,{ }^{* * *} p<0.001$ statistically significant relative to control (saline).

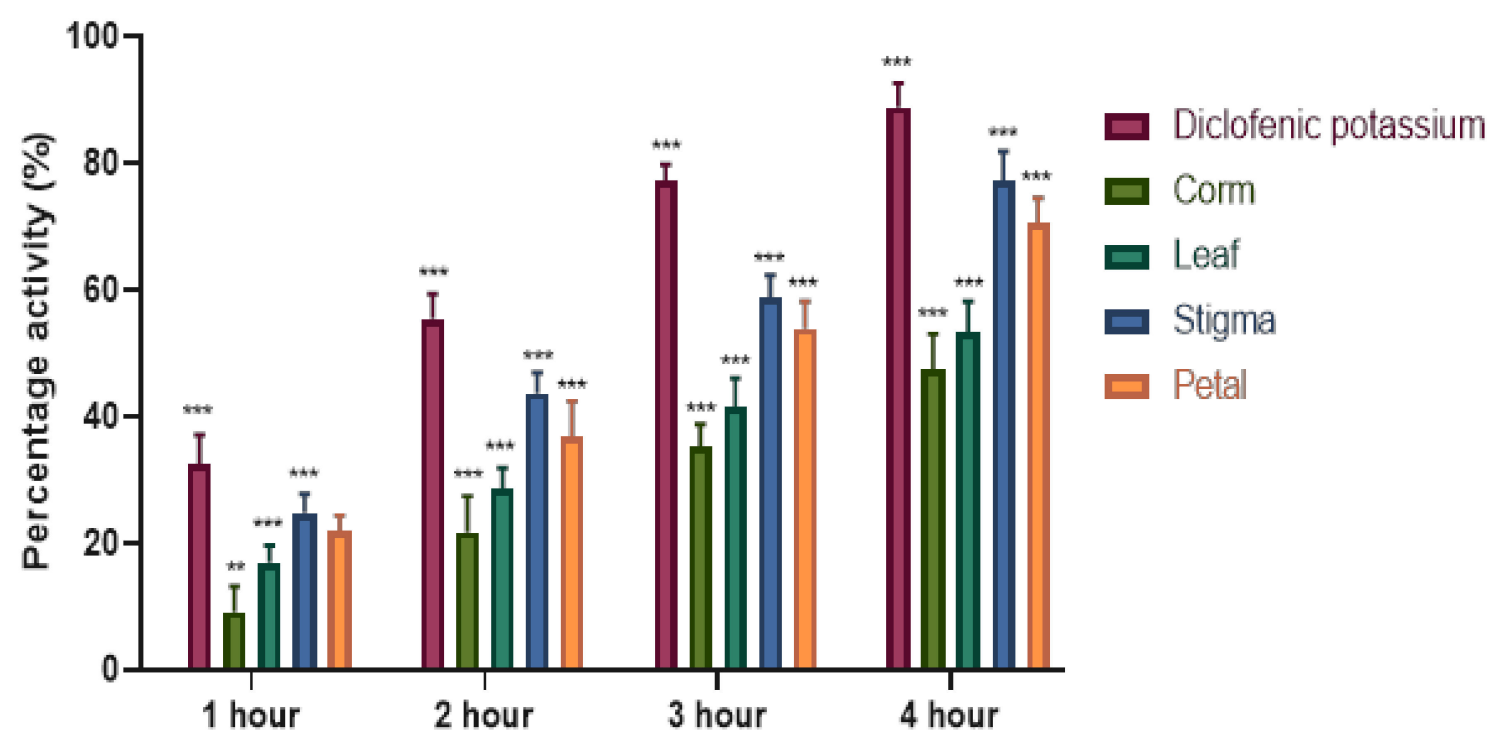

Figure 3. Percentage edema inhibition of C. sativus ethanolic extracts at selected time period in mice. Each value is represented as mean \pm S.D. Where, ${ }^{*} p<0.05,{ }^{* *} p<0.01,{ }^{* * *} p<0.001$ statistically significant relative to control (saline).

\subsection{Anticoagulant Assay}

The blood clotting activity of saffron extracts was investigated using the capillary tube method. The results presented in Figure 4 show the effects of oral administration of saffron extracts and aspirin on coagulation time in mice. As a reference drug, the anticoagulant aspirin $(10 \mathrm{mg} / \mathrm{kg})$ significantly increased blood clotting time $(108.5 \pm 8.59 \mathrm{~s})$ compared to the control group, saline (38.33 $\pm 4.92 \mathrm{~s})$. SEE was the major identified anticoagulant extract showing prominent and significant anticoagulant effect with coagulation time of $101.66 \pm 7.20 \mathrm{~s}$ followed by PCC $(86.50 \pm 6.89 \mathrm{~s})$, respectively. LEE, however, had a moderate inhibitory effect on coagulation activity with a clotting time of $66.83 \pm 6.17 \mathrm{~s}$. CEE, on the other hand, was unable to prolong the blood clotting time $(42.83 \pm 6.27 \mathrm{~s})$ and showed an almost equal response to saline, representing the neutral effect of the selected extract. 


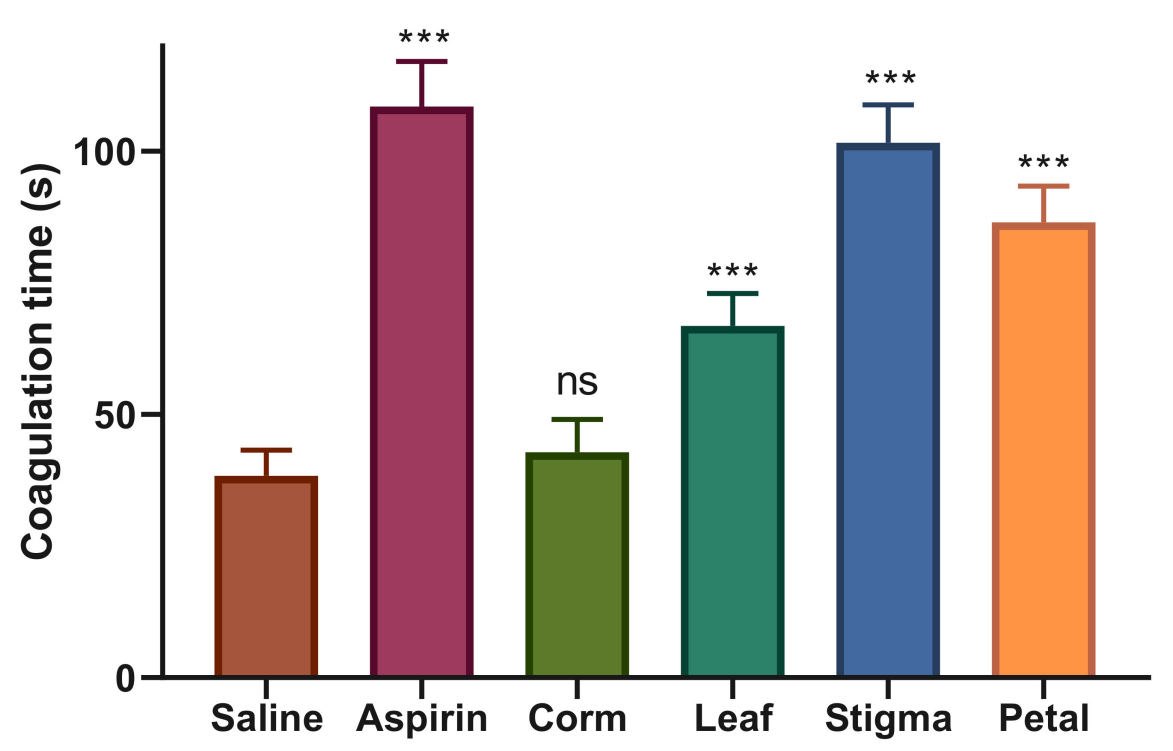

Figure 4. Anticoagulant effect of $C$. sativus ethanolic extracts. Each value is represented as mean \pm S.D. Where, ${ }^{*} p<0.05,{ }^{* *} p<0.01,{ }^{* * *} p<0.001$ statistically significant relative to control (saline).

\subsection{Antidepressant Activity}

The antidepressant activity of orally administered saffron ethanolic extracts was tested by forced swimming test, and findings in the form of immobility time are graphically depicted in Figure 5. Positive control group administered with drug, fluoxetine $\mathrm{HCl}$ produced a strong antidepressant effect $(41.33 \pm 4.71 \mathrm{~s})$ at the concentration of $10 \mathrm{mg} / \mathrm{kg}$ against the negative control, saline $(141.16 \pm 6.40$ s). Furthermore, saffron ethanolic extracts significantly attenuated immobility time in mice when compared with the saline-treated control group. At the dose of $800 \mathrm{mg} / \mathrm{kg}$, PEE represented itself as a potential antidepressant candidate showing a significant reduction in immobility time $(69.66 \pm 7.63$ s) with respect to control and equivalent to the standard drug followed by SEE (76.66 $\pm 6.56 \mathrm{~s})$. CEE significantly declined the mean time spent by mice in the immobile state (96.50 $\pm 6.28 \mathrm{~s})$, signifying moderate antidepressant effect, whereas LEE exhibited mild activity (106.83 $\pm 6.24 \mathrm{~s})$ by significantly attenuating immobility time with respect to serine, but not equivalent to fluoxetine $\mathrm{HCl}$. 


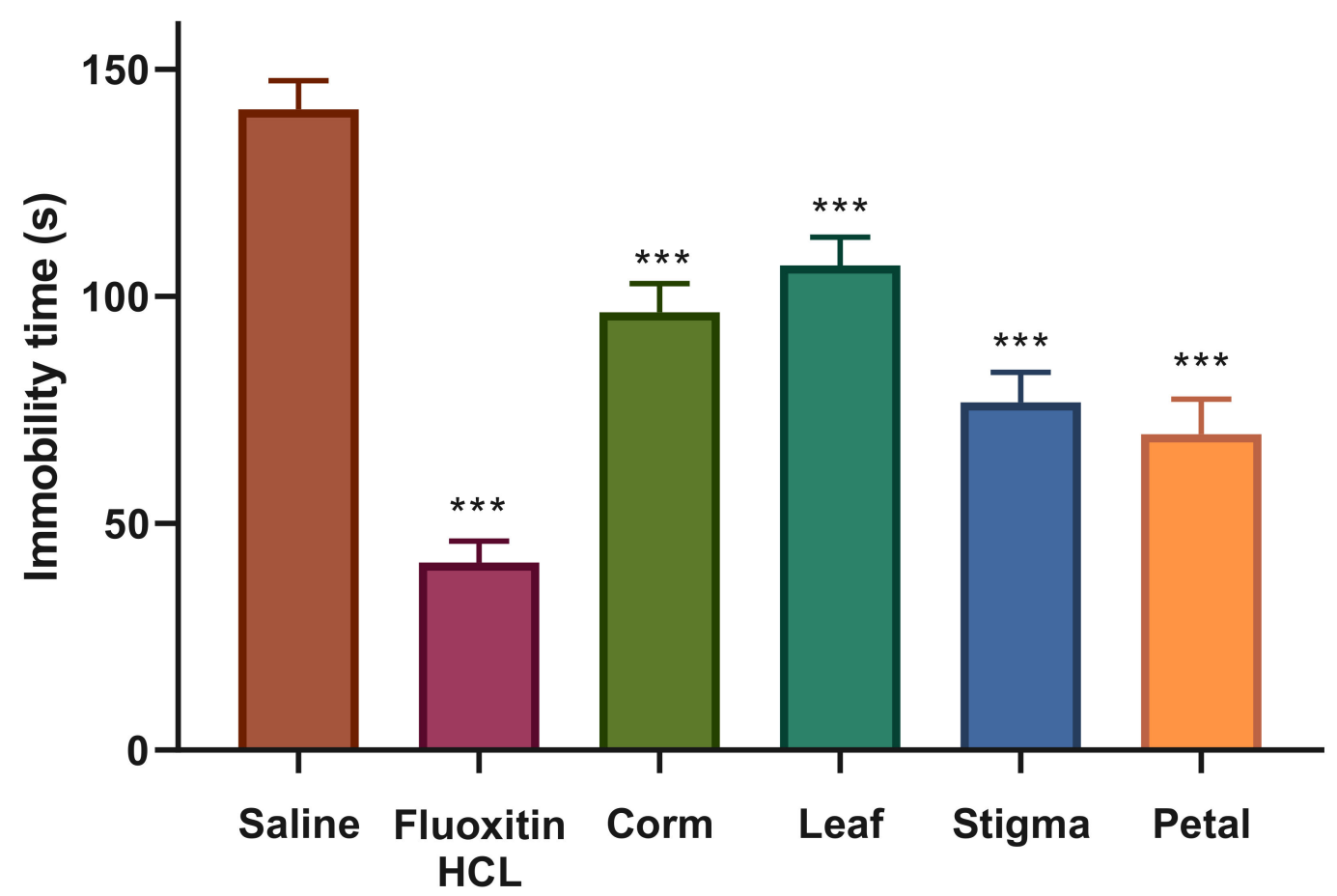

Figure 5. Antidepressant effect of $C$. sativus ethanolic extracts. Each value is represented as mean \pm S.D. Where, ${ }^{*} p<0.05,{ }^{* *} p<0.01,{ }^{* * *} p<0.001$ statistically significant relative to control (saline).

\section{Discussion}

Saffron is an extraordinarily rich source of nutraceutical and pharmaceutical properties that exhibit numerous health benefits and pharmacological effects [42]. In the present study, we have evaluated the analgesic, anti-inflammatory, anticoagulant, and antidepressant activities of saffron ethanolic extracts in mice. The selection of $80 \%$ ethanol and/or ethanolic extracts was chosen for the study due to their efficiency against cancer [43,44], blood pressure [45,46], inflammation [47], and nociception [48,49]. None of the orally administered saffron extracts $(800 \mathrm{mg} / \mathrm{kg})$ caused any mortality or prominent behavioral abnormalities in mice during the 7-days acute toxicity study. In literature, toxicological reports regarding saffron safety are not uniform. Iranshahi et al. [50] assessed the toxicity level of $800 \mathrm{mg} / \mathrm{kg}$ SEE, PEE, stigma aqueous extract (SAE), and petal aqueous extract (PAE) and found no toxicological signs on mice. In another study, the maximum non-toxic dose of SEE and PEE was reported as 2 and $8 \mathrm{~g} / \mathrm{kg}$, respectively [48]. Furthermore, $\mathrm{LD}_{50}$ values of intraperitoneal administered petal and stigma extracts in mice were 6 and $1.6 \mathrm{~g} / \mathrm{kg}$, respectively [51]. Similarly, no mortality of mice was reported within 2 days of study with high oral and intraperitoneal doses $(3 \mathrm{~g} / \mathrm{kg})$ of the active constituent of saffron, crocin, in mice [52].

The hot plate is one of the oldest and frequently used animal models to quantify "pain-like" behaviors in rodents [53]. Based on the species and strain of rodents used in clinical studies, nearly 12 different behaviors, including grooming, freezing, sniffing, licking, stamping of the legs, leaning, and jumping, have been measured in the hot plate assay [54]. In the present study, hot plate analgesic assay of saffron extracts demonstrated a time-dependent activity. Among all the saffron extracts, SEE exhibited the highest analgesic value in delaying the mean paw licking time (13.50 $\pm 0.28 \mathrm{~s})$ by suppressing nociception in paws. PEE also delayed the onset time of licking response (11.13 $\pm 0.35 \mathrm{~s})$. However, CEE and LEE exhibited weak analgesic activity of $22 \%$ and $29 \%$ at $2 \mathrm{~h}$, respectively. Good analgesic drugs suppress the activity of nociceptors and exhibit the least number of lickings in animals. As per findings, SEE, and PEE thus were found as potent analgesic agents. The maximum analgesic activity of SEE might be due to the presence of carotenoids such as crocetin, crocin, picrocrocin, and safranal, as carotenoids have been reported to suppress the synthesis of prostaglandin synthetase [55]. 
This speculation is supported by another study where 0.1 and $0.2 \mathrm{~g} / \mathrm{kg}$ crocin showed significant anti-edematogenic potential in histamine-induced paw edema in rats [56]. However, according to Hosseinzadeh and Younesi [48], aqueous and ethanolic stigma and petal extracts of saffron at any dose exerted no significant analgesic effect in mice. They suggested that the extracts might not act through central mechanisms, although drugs that alter the animal's motor ability may enhance the licking duration on the hot plate method without affecting the central nervous system.

Inflammation serves as a body's defensive biological response to damaged cells and injured tissue. The existence of edema is amongst the major signs of inflammation [57]. Carrageenan-induced paw edema is an established method to investigate the anti-edematous activity of natural products in rodents [58,59]. In the present study, the anti-inflammatory potential of saffron ethanolic extracts was studied after a sub-planter injection of $1 \% \lambda$-carrageenan into mice. Test samples represented significant anti-edematous potential by regulating biphasic acute inflammatory response induced by carrageenan and showed the highest edema inhibition in mice after $4 \mathrm{~h}$. Carrageenan induces the inflammatory process in two phases. The initial phase, which occurs during the first $2.5 \mathrm{~h}$ post-carrageenan injection, attributes to the release of mediators like serotonin, histamine, and bradykinin on vascular permeability. Serotonin and histamine are produced in the first $1.5 \mathrm{~h}$, while bradykinin is produced within $2.5 \mathrm{~h}$ post-carrageenan injection [60]. The final phase occurs from 2.5 to $6 \mathrm{~h}$ after carrageenan injection, is associated with the overproduction of prostaglandins in tissues $[58,61]$. In addition to these mediators, Nitric Oxide (NO) is also reported to play a key role in carrageenan-induced acute inflammation $[62,63]$. Among all the extracts, SEE effectively inhibited the increase in paw volume of carrageenan-induced edema showing a maximum percentage of edema inhibition (77.33\%) at the end of $4 \mathrm{~h}$ followed by PEE $(70.50 \%)$ at $800 \mathrm{mg} / \mathrm{kg}$ dose. Diclofenac potassium used as a standard drug reduced paw edema volume by $88.87 \%$. Therefore, it can be assumed that the active constituents of the extract might be responsible for the inactivation of inflammation process whose mechanism of action need to be studied. Phytochemicals screening of SAE, SEE, PAE, and PEE on acute inflammation by xylene-induced ear edema indicated that only SAE and SEE at higher doses possessed anti-inflammatory effects in mice. However, SAE, SEE, and PEE showed significant activity against chronic inflammation using formalin-induced edema in rat paw [48]. In another study, saffron aqueous extract suppressed formalin-induced paw edema in the chronic inflammation but failed to show activity against the acute phase of a formalin test [64]. Similarly, intraperitoneal injection of stigma constituent, crocin at concentrations of 0.1 and $0.2 \mathrm{~g} / \mathrm{kg}$ significantly attenuated paw thickness and infiltration of neutrophils in paw tissues [56]. Kumar et al. [65] examined various petal extracts of $C$. sativus Cashmerianus to assess the anti-inflammatory effect by carrageenan-induced paw edema method. Among all the extracts, methanol extract $(400 \mathrm{mg} / \mathrm{mL})$ exhibited $63.16 \%$ inhibition of paw volume, followed by aqueous $(57.89 \%)$ and chloroform (50\%) extracts. The phytochemical profile of C. sativus petal suggests that the anti-inflammatory properties of PEE might be due to the presence of nutraceutical compounds, particularly flavonoids (kaempferol, $12.6 \% w / w$ ) by modulating the gene and protein expression of inflammatory molecules [66].

The normal hemostatic process is meant to stop a cut or wound on blood vessels through platelet thrombus formation; subsequently, there is an eventual elimination of the plug when healing is complete. It is a delicate multiphase mechanism that requires the interaction of platelets and the coagulation factors with blood vessels. A defect in any of these phases can result in thrombosis or hemorrhage [67]. Extracts of various herbal plants have been used for their hemostatic role in wound healing, anti-infective, and antineoplastic properties [68]. Ankaferd Blood Stopper, an herbal extract from five plants (Urtica dioica, Alpinia officinarum, Vitis vinifera, Thymus vulgaris, and Glycyrrhiza glabra) is approved for the management of external hemorrhage and post-surgery dental bleedings in Turkey to attenuate blood clotting time effectively [69]. Additionally, crude extracts of Fagonia cretica (74.6\%), Hedera nepalensis $(73.8 \%)$, and Phytolacca latbenia $(67.3 \%)$ revealed promising anticoagulant effect by delaying blood clotting time to $86.9 \mathrm{~s}, 84.3 \mathrm{~s}$, and $67.5 \mathrm{~s}$, respectively [70]. In this study, saline and aspirin showed a clear line of difference between the coagulation and anticoagulation by depicting 
blood clotting time of $38.33 \mathrm{~s}$ and $108.5 \mathrm{~s}$, respectively. The most significant anticoagulant effect was reported by SEE with a coagulation time of $101.66 \mathrm{~s}$ followed by PEE ( $86.5 \mathrm{~s})$, respectively. LEE showed a blood clotting time of $66.83 \mathrm{~s}$, representing a moderate inhibitory effect on coagulation activity. CEE was least effective in anticoagulation property and showed an almost equal response to saline, indicating a neutral effect of the selected extract, which can be used in the treatment of blood clotting disorders such as hemophilia. It is said that the corms of C. sativus Cartwrightianus have a protein factor involved in human platelet aggregation [71]. However, 5 years later, it was reported that it contains both activator/inducer of platelet aggregation [72]. Crocin delayed blood clotting time and mitigated respiratory distress as a result of pulmonary thrombosis in mice, inhibited thrombosis in rats, and suppressed platelet aggregation in rabbits [73]. Crocetin significantly reduced collagen- and ADP-induced platelet aggregation but failed to reduce arachidonic acid-induced platelet aggregation [74]. Besides that, crocetin significantly reduced dense granule secretion, while neither platelets adhesion to collagen nor cyclic AMP level was affected by crocetin [75]. Saffron stigma tablets ( $200 \mathrm{and} 400 \mathrm{mg} /$ day) assessed for short-term safety and tolerability in a limited number of volunteers showed that only $200 \mathrm{mg}$ of saffron tablets reduced International Normalize Ratio, platelets, and coagulation time [76]. Later, in a double-blind, placebo-controlled clinical study with a large sample size, saffron tablets ( 200 and $400 \mathrm{mg} /$ day) administration failed to show any major effect on coagulant and anticoagulant system after one month. The authors suggested that the case reports of hemorrhagic complications might be due to the high saffron dose, high period of consumption, or idiosyncrasy activities [77].

Depression is one of the most serious psychiatric disorders affecting approximately $4.7 \%$ of the global population and is ranked as the eleventh most frequent cause of disease burden worldwide [78]. Most of the patients have many concerns about commencing synthetic antidepressants in their recommended doses due to the anticipated adverse reactions such as libido, constipation, dry mouth, and dizziness [79]. Hence, extracts of medicinal plants provide the most effective sources of novel drugs showing promising results with minimum side effects in the routine treatment of depression [80,81]. The Forced Swimming Test (FST) or Porsolt swim test, is the most frequently used test to screen antidepressants among all rodents with more reliability, sensitivity, and specificity [82]. Immobility or the flouting response of rodents in FST is traditionally considered an indication of depression and anxiety [83]. During the FST, treatment of antidepressant drugs attenuate immobility, prolong its onset and delay active escape behaviors of the animal [84]. In the present study, a prominent difference in immobility time of saline (141.16 s) and fluoxetine $\mathrm{HCl}(41.33 \mathrm{~s})$ used as a negative and positive control, respectively, was observed, representing the reliability of the test. Furthermore, the administration of saffron extracts showed a significant effect on reducing the immobility time compared to the saline-treated group. PEE represented itself as a potential antidepressant drug showing a notable diminution in the immobility period (69.66 s) followed by SEE (76.66 s). Moreover, CEE (96.50 s) indicated moderate antidepressant effect, whereas LEE (106.83 s) exhibited mild activity. The potent antidepressant effect exhibited by petal can be strongly linked to the presence of natural flavonoid, kaempferol as it significantly attenuated immobility behaviors in rats and mice and showed an almost similar response to fluoxetine [85]. Similarly, in an 8-week double-blind, randomized clinical study, dried saffron petal (15 mg bid) had similar antidepressant effects as fluoxetine (15 mg bid) in treating patients with mild-to-moderate depression and no significant differences in observed side effects [34]. In an investigation comparing the efficacy of saffron stigma and corms with fluoxetine against depression, petroleum ether, and dichloromethane fractions of saffron stigma and corms significantly reduced the immobility time in the tail suspension and forced swimming test at all doses $(150,300$, and $600 \mathrm{mg} / \mathrm{kg}$ ) without altering the locomotor behavior of mice during the open-field test. The authors highlighted that the antidepressant effect of stigma extracts could be due to crocin analogs, particularly crocin 1 . However, HPLC analysis of corm extract revealed the absence of safranal, crocin, crocetin, or kaempferol compounds, assuming the presence of other bioactive compounds in saffron corms showing a potent antidepressant effect which need to be further explored [80]. The 
promising antidepressant activity of saffron secondary metabolites opens the doors for further studies to understand the mode of action in medicinal plants.

\section{Materials and Methods}

\subsection{Plant Material}

Saffron corms obtained from the safranor company, France, were planted in plastic trays and pots containing black soil in August. The soil texture of experimental black soil was a clay-loam structure containing $2.74 \%$ of total organic carbon and $0.04 \%$ of total nitrogen, in addition to $7 \mathrm{ppm}$ of phosphorus, $331.5 \mathrm{ppm}$ of potassium, $64 \mathrm{ppm}$ of calcium, $75.6 \mathrm{ppm}$ of magnesium, and $25.3 \mathrm{ppm}$ of sodium. The corms were incubated in a temperature-controlled $\left(18 \pm 1^{\circ} \mathrm{C}\right)$ room under $16 \mathrm{~h}$ photoperiod illuminated with white fluorescent tubes at an irradiance of nearly $40 \mu \mathrm{mol} \mathrm{m} \mathrm{m}^{-2} \mathrm{~s}^{-1}$. Different saffron parts were collected as per life span of the plant, i.e., petal and stigma were handpicked during October, leaves were collected in May, and smaller corms weighing less than $2 \mathrm{~g}$ were harvested in June. Individual parts were air-dried under shade for 7 weeks and ground to powder.

\subsection{Chemicals}

For animal experiments, all the chemicals, including aspirin, diclofenac potassium, fluoxetine $\mathrm{HCl}$, ethanol, and carrageenan were purchased from Sigma. All chemicals used in the experiment were analytical grade.

\subsection{Sample Extraction}

Powder samples were macerated in ethanol/water $(80 \%, v / v)$ for a week at room temperature. The mixture was subsequently filtered with Whatman filter paper 1 (Sigma-Aldrich, St. Louis, MO, USA) and concentrated by rotary evaporator under reduced pressure at $45^{\circ} \mathrm{C}$. Semi-liquid extracts were further allowed to dry in the fume hood. The crude extracts were freeze-dried and stored in sealed tubes at $-20{ }^{\circ} \mathrm{C}$ for in vivo studies.

\subsection{Standard and Test Drugs Preparation}

Ethanolic extracts of saffron were prepared as $0.08 \mathrm{~g} / \mathrm{mL}$ in $10 \%$ DMSO while standard drugs were dissolved in saline water $(0.01 \mathrm{~g} / \mathrm{mL}$ of $0.9 \% \mathrm{NaCl})$ and treated orally at $1 \mathrm{~mL} / 100 \mathrm{~g}$ of mouse body weight. One optimal dose $(800 \mathrm{mg} / \mathrm{kg})$ showing maximum effect with no lethal consequences to mice was selected in this study, as reported previously [50].

\subsection{Animals}

Adult albino mice (Swiss strain) of either sex between 30-40 g were provided by Veterinary Research Institute Peshawar, Pakistan. All the mice were housed in aluminum cages (grade 304) under controlled natural $12 / 12 \mathrm{~h}$ light/dark cycle, temperature $\left(21 \pm 2{ }^{\circ} \mathrm{C}\right)$, and humidity $(50-60 \%)$, and received tap water ad libitum and standard diet at the Animal House, Quaid-I-Azam University (QAU) Islamabad, Pakistan. Mice were acclimatized in this environment for seven days before the experiments. All the experiments were carried out between 10:00 and 17:00. The study protocol (Bch 0275) for laboratory animals was in accordance with the recommendations of the Institutional Animal Ethics Committee (QAU Islamabad), and all the precautionary measures were followed to reduce animal's fear and suffering.

\subsection{Study Design}

Mice were weighed, marked with numbers, and split into 6 groups, each containing 6 mice. All the samples were administered by oral gavage. Group 1 received saline $(0.9 \%)$ and was used as a negative control. Mice in group 2 were given a dose of $10 \mathrm{mg} / \mathrm{kg}$ standard drugs (aspirin for analgesic and anticoagulant, diclofenac potassium for anti-inflammatory, and fluoxetine $\mathrm{HCl}$ for antidepressant 
assay) used as a positive control. Group 3, 4, 5, and 6 were administered with a dose of $800 \mathrm{mg} / \mathrm{kg}$ CEE, LEE, SEE, and PEE, respectively.

\subsubsection{Acute Toxicity Study}

The acute toxicity study of each tested sample was undertaken in accordance with the guidelines of the Organization for Economic Cooperation and Development (OECD). Albino mice $(n=6)$ were administered orally with $800 \mathrm{mg} / \mathrm{kg}$ of each extract and observed for any changes in behavior and mortality at intervals of $0,5,10,15,20$, and $24 \mathrm{~h}$. Mice were examined for an additional 6 days for any signs of late morbidity and mortality.

\subsubsection{Hot Plate Analgesic Assay}

The test first reported by Eddy and Leimbach [86], with some modifications, was performed to measure the analgesic activity of saffron extracts. The standard drug, aspirin $(10 \mathrm{mg} / \mathrm{kg})$, and saline $(1 \mathrm{~mL} / \mathrm{kg})$ were served as a positive and negative control, respectively. The parameter recorded was based on the latency time for fore- and hind-paw licking and/or jumping responses by placing the mice on the surface of a hot-plate (IITC Life Science, USA) set at a temperature of $55 \pm 1{ }^{\circ} \mathrm{C}$ and initial latency time (Ti) was calculated by taking the mean of two readings. Animals with baseline latencies of $<5 \mathrm{~s}$ or $>30 \mathrm{~s}$ were ignored from the study. The final latency time (Tf) was noted after administration of the drug for each group at the intervals of $0.5,1$, and $2 \mathrm{~h}$, with a cut off time of $30 \mathrm{~s}$. The tested extracts $(0.8 \mathrm{~g} / \mathrm{kg})$ were administered orally, and standard (aspirin, $10 \mathrm{mg} / \mathrm{kg})$ was administered subcutaneously. The percentage analgesia (PA) was measured using the equation:

$$
\mathrm{PA}=\left(\frac{\mathrm{Tf}-\mathrm{Ti}}{\mathrm{Ti}}\right) \times 100
$$

\subsubsection{Carrageenan-induced Paw Edema Test}

C. sativus ethanolic extracts were examined for their anti-inflammatory activities using the carrageenan-induced paw edema test as described by Winter et al. [87]. The test is based on the principle to assess acute anti-inflammatory activity in the hind paws of mice by developing inflammatory models with carrageenan, a sulfated polysaccharide agent that triggers inflammation. In this test, diclofenac potassium $(10 \mathrm{mg} / \mathrm{kg})$ was used as a positive control, and saline $(1 \mathrm{~mL} / \mathrm{kg})$ served as a negative control to compare the anti-inflammatory effects. Before experimentation, mice were fasted for $24 \mathrm{~h}$ but had access to water. For edema induction, $1 \% \lambda$-carrageenan $(0.1 \mathrm{~mL})$, prepared in $1 \%$ saline was injected into the sub planter tissue of mice left hind paw $1 \mathrm{~h}$ after administration of the drug. The basal volume of the paw was recorded just before and after injection of $\lambda$-carrageenan at $0,1,2,3$, and $4 \mathrm{~h}$ by digital plethysmometer (UGO Basile, 7140). For every interval, all the data were recorded in triplicate. The degree of swelling was calculated by the delta volume (A-B), where " $A$ " shows the mean volume of the left hind paw after and " $\mathrm{B}$ " before the treatment of $\lambda$-carrageenan. The percentage edema inhibition (PEI) was measured using the equation:

$$
\mathrm{PEI}=\left(\frac{\mathrm{A}-\mathrm{B}}{\mathrm{A}}\right) \times 100
$$

\subsubsection{Anticoagulant}

Blood clotting activity of saffron extracts was evaluated by the capillary tube method reported by Ismail and Mirza [84]. One hour after oral administration of the dose, the mouse tail was disinfected with spirit and prickled using a lancet. The tail was pressed firmly to get a bigger drop of blood and collected in capillary tubes. The time of appearance of the blood drop on the cut tail was recorded. The tubes were wrapped and maintained at $37 \pm 1{ }^{\circ} \mathrm{C}$ in a water bath. Small portions of each tube were broken at regular intervals of $10 \mathrm{~s}$, until fibrin thread appeared. The blood coagulation time was 
measured by considering the appearance of a blood drop as a starting point and thread formation as an endpoint.

\subsubsection{Forced Swimming Test}

The forced swim test (FST) described by Porsolt et al. [88] was used to screen the extracts of saffron for their antidepressant activity. On day first, mice were forced to swim individually in a glass tank of $40 \mathrm{~cm}$ height and $18 \mathrm{~cm}$ diameter containing water up to $30 \mathrm{~cm}$ under natural light. The water temperature was adjusted to $25 \pm 1{ }^{\circ} \mathrm{C}$. The water level was adjusted in such a way that mice could only touch the bottom of the tank with the tip of the tail. After 15 min exposure in the tank, mice were evacuated, dried off with a paper towel, and shifted to their home cage. The next day, saline (1 $\mathrm{mL} / \mathrm{kg})$ and fluoxetine $\mathrm{HCl}(10 \mathrm{mg} / \mathrm{kg})$ served as a negative and positive control, respectively, along with saffron extracts $(800 \mathrm{mg} / \mathrm{kg}$ ) were administered $30 \mathrm{~min}$ before the experiment. Mice were allowed to swim freely for $6 \mathrm{~min}$ in the tank, and swimming behaviors were recorded with a video camera. Before each test, freshwater was introduced. Animals were placed one by one, and after every $2 \mathrm{~min}$, immobility time was calculated in the last $4 \mathrm{~min}$ of swimming practice using a stopwatch. Immobility time is the time when the mouse stopped all additional movements other than those required for survival or balancing of their body.

\subsection{Statistical Analysis}

Data were expressed as mean along with standard deviation. Significant difference between groups was analyzed with One-way ANOVA in anticoagulant and antidepressant assays and two-way ANOVA in analgesic and anti-inflammatory assays followed by the Post Hoc Dunnett test. Graphs were made in GraphPad Prism 5.0 (La Jolla, CA, USA). The results were considered to be significant at $p<0.05$.

\section{Conclusions}

To the best of our knowledge this is the first report of CEE, LEE, SEE, and PEE from in vivo grown Crocus sativus L. to determine anti-inflammatory, analgesic, anticoagulant, and antidepressant properties in mice. SEE and PEE were evinced as a safe natural remedy to treat pain, inflammation, depression, and the coagulation system. The above results clearly indicate that saffron is an excellent source of bioactive compounds having great potential as nutraceuticals and health benefits. These properties can be linked to intrinsic active compounds such as carotenoids and flavonoids found in the highest amounts in stigma and petals, respectively. However, further epidemiological investigations, laboratory research, and clinical trials are required to isolate the pharmacologically active molecules that contribute to the observed effects and to explicate the possible mechanism of action and effect of the plant on various critical illnesses and medicinal formulations.

Author Contributions: Conceptualization, A.K., N.A.M. and H.I.; methodology, A.K., H.I. and S.L.; software, A.K. and H.I.; validation, N.A.M. and R.M.T.; formal analysis, H.I., A.A.K.K., Y.A.J.F., I.M.A.Z., S.A.A.T., Z.K., Y.A., A.A., A.N. and B.M.; investigation, H.I., S.L., A.N., A.A.K.K. and B.M.; data curation, A.K. and H.I.; writing-original draft preparation, A.K. and N.A.M.; writing-review and editing, Y.A., I.M.A.Z, S.A.A.T., A.N., A.A.K.K., Z.K., Y.A.J.F., A.A., N.A.M. and R.M.T.; supervision, N.A.M., R.M.T. and B.M. All authors have read and agreed to the published version of the manuscript.

Funding: This research received no external funding.

Conflicts of Interest: The authors declare no conflict of interest. 


\section{References}

1. Koocheki, A.; Rezvani Moghaddam, P.; Aghhavani-Shajari, M.; Fallahi, H.R. Corm weight or number per unit of land: Which one is more effective when planting corm, based on the age of the field from which corms were selected? Ind. Crops Prod. 2019, 131, 78-84. [CrossRef]

2. Cardone, L.; Castronuovo, D.; Perniola, M.; Cicco, N.; Candido, V. Saffron (Crocus sativus L.), the king of spices: An overview. Sci. Hortic. 2020, 272, 109560. [CrossRef]

3. Fallahi, H.R.; Aghhavani-Shajari, M.; Branca, F.; Davarzani, J. Effect of different concentrations of saffron corm and leaf residue on the early growth of arugula, chickpea and fenugreek under greenhouse conditions. Acta Agric. Slov. 2018, 111, 51-61. [CrossRef]

4. Tsaftaris, A.; Pasentsis, K.; Argiriou, A. Cloning and Characterization of FLOWERING LOCUS T-Like Genes from the Perennial Geophyte Saffron Crocus (Crocus sativus). Plant Mol. Biol. Rep. 2013, 31, 1558-1568. [CrossRef]

5. Verma, S.K.; Das, A.K.; Cingoz, G.S.; Uslu, E.; Gurel, E. Influence of nutrient media on callus induction, somatic embryogenesis and plant regeneration in selected Turkish crocus species. Biotechnol. Rep. 2016, 10, 66-74. [CrossRef]

6. Kafi, M.; Kamili, A.N.; Husaini, A.M.; Ozturk, M.; Altay, V. An Expensive Spice Saffron (Crocus sativus L.): A Case Study from Kashmir, Iran, and Turkey. In Global Perspectives on Underutilized Crops; Ozturk, M., Hakeem, K.R., Ashraf, M., Ahmad, M.S.A., Eds.; Springer International Publishing: Cham, Switzerland, 2018; pp. 109-149.

7. Chahine, N.; Chahine, R. Protecting Mechanisms of Saffron Extract Against Doxorubicin Toxicity in Ischemic Heart. In Saffron: The Age-Old Panacea in a New Light; Sarwat, M., Sumaiya, S., Eds.; Elsevier: Amsterdam, The Netherlands, 2020; pp. 141-154.

8. Hadizadeh, F.; Khalili, N.; Hosseinzadeh, H.; Khair-Aldine, R. Kaempferol from saffron petals. Iran. J. Pharm. Res. 2010, 2, 251-252.

9. Mykhailenko, O.; Kovalyov, V.; Goryacha, O.; Ivanauskas, L.; Georgiyants, V. Biologically active compounds and pharmacological activities of species of the genus Crocus: A review. Phytochemistry 2019, 162, 56-89. [CrossRef]

10. José Bagur, M.; Alonso Salinas, G.L.; Jiménez-Monreal, A.M.; Chaouqi, S.; Llorens, S.; Martínez-Tomé, M.; Alonso, G.L. Saffron: An Old Medicinal Plant and a Potential Novel Functional Food. Molecules 2018, $23,30$. [CrossRef]

11. Anuar, N.; Taha, R.M.; Mahmad, N.; Othman, R. Identification of crocin, crocetin and zeaxanthin in Crocus sativus grown under controlled environment in Malaysia. Pigm. Resin Technol. 2018, 47, 502-506. [CrossRef]

12. Mzabri, I.; Addi, M.; Berrichi, A. Traditional and Modern Uses of Saffron (Crocus Sativus). Cosmetics 2019, 6, 63. [CrossRef]

13. Hosseinzadeh, H.; Nassiri-Asl, M. Avicenna's (Ibn Sina) the canon of medicine and saffron (Crocus sativus): a review. Phytother. Res. 2013, 27, 475-483. [CrossRef] [PubMed]

14. Horozić, E. Effects of extraction solvent/technique on the antioxidant and antimicrobial activity of spring saffron (Crocus vernus (L.) Hill). Acta Med. Salin. 2020, 49, 19-22. [CrossRef]

15. Zhang, K.; Wang, L.; Si, S.; Sun, Y.; Pei, W.; Ming, Y.; Sun, L. Crocin improves the proliferation and cytotoxic function of T cells in children with acute lymphoblastic leukemia. Biomed. Pharmacother. 2018, 99, 96-100. [CrossRef] [PubMed]

16. Sun, C.; Nile, S.H.; Zhang, Y.; Qin, L.; El-Seedi, H.R.; Daglia, M.; Kai, G. Novel Insight into Utilization of Flavonoid Glycosides and Biological Properties of Saffron (Crocus sativus L.) Flower Byproducts. J. Agric. Food Chem. 2020, 68, 10685-10696. [CrossRef]

17. Khoulati, A.; Ouahhoud, S.; Mamri, S.; Alaoui, K.; Lahmass, I.; Choukri, M.; Kharmach, E.Z.; Asehraou, A.; Saalaoui, E. Saffron extract stimulates growth, improves the antioxidant components of Solanum lycopersicum L., and has an antifungal effect. Ann. Agric. Sci. 2019, 64, 138-150. [CrossRef]

18. Boskabady, M.H.; Farkhondeh, T. Antiinflammatory, Antioxidant, and Immunomodulatory Effects of Crocus sativus L. and its Main Constituents. Phytother. Res. 2016, 30, 1072-1094. [CrossRef] 
19. Yousefi, F.; Arab, F.L.; Rastin, M.; Tabasi, N.S.; Nikkhah, K.; Mahmoudi, M. Comparative assessment of immunomodulatory, proliferative, and antioxidant activities of crocin and crocetin on mesenchymal stem cells. J. Cell. Biochem. 2020, 1-14. [CrossRef]

20. Bhandari, P.R. Crocus sativus L. (saffron) for cancer chemoprevention: A mini review. J. Tradit. Complement. Med. 2015, 5, 81-87. [CrossRef]

21. Mohammadzadeh-Moghadam, H.; Nazari, S.M.; Shamsa, A.; Kamalinejad, M.; Esmaeeli, H.; Asadpour, A.A.; Khajavi, A. Effects of a topical saffron (Crocus sativus L.) gel on erectile dysfunction in diabetics: A randomized, parallel-group, double-blind, placebo-controlled trial. Evid. Based Complement. Altern. Med. 2015, 20, $283-286$. [CrossRef]

22. Hosseinzadeh, H.; Ghenaati, J. Evaluation of the antitussive effect of stigma and petals of saffron (Crocus sativus) and its components, safranal and crocin in guinea pigs. Fitoterapia 2006, 77, 446-448. [CrossRef]

23. Saadat, S.; Shakeri, F.; Boskabady, M.H. Comparative Antitussive Effects of Medicinal Plants and Their Constituents. Altern. Ther. Health Med. 2018, 24, 36-49. [PubMed]

24. Arimitsu, J.; Hagihara, K.; Ogawa, K. Potential Effect of Saffron as an Antiplatelet Drug in Patients with Autoimmune Diseases. J. Altern. Complement. Med. 2014, 20, A90. [CrossRef]

25. Moazen-Zadeh, E.; Abbasi, S.H.; Safi-Aghdam, H.; Shahmansouri, N.; Arjmandi-Beglar, A.; Hajhosseinn Talasaz, A.; Salehiomran, A.; Forghani, S.; Akhondzadeh, S. Effects of Saffron on Cognition, Anxiety, and Depression in Patients Undergoing Coronary Artery Bypass Grafting: A Randomized Double-Blind Placebo-Controlled Trial. J. Altern. Complement. Med. 2018, 24, 361-368. [CrossRef] [PubMed]

26. Hosseini, S.A.; Zilaee, M.; Shoushtari, M.H.; Ghasemi dehcheshmeh, M. An evaluation of the effect of saffron supplementation on the antibody titer to heat-shock protein (HSP) 70, hsCRP and spirometry test in patients with mild and moderate persistent allergic asthma: A triple-blind, randomized placebo-controlled trial. Respir. Med. 2018, 145, 28-34. [CrossRef] [PubMed]

27. Azimi, P.; Abrishami, R. Comparison of the Effects of Crocus Sativus and Mefenamic Acid on Primary Dysmenorrhea. J. Pharm. Care 2018, 4, 75-78.

28. Mohammad, N.S.; Atefeh, A.; Mahbobeh, N.S.; Davood, S.; Shakiba, M.; Hamidreza, B.T.; Mehrpour, M. Comparison of Saffron versus Fluoxetine in Treatment of Women with Premenstrual Syndrome: A Randomized Clinical Trial Study. Indian J. Med. Forensic Med. Toxicol. 2020, 14, 1760-1765.

29. Fernández-Albarral, J.A.; de Hoz, R.; Ramírez, A.I.; López-Cuenca, I.; Salobrar-García, E.; Pinazo-Durán, M.D.; Ramírez, J.M.; Salazar, J.J. Beneficial effects of saffron (Crocus sativus L.) in ocular pathologies, particularly neurodegenerative retinal diseases. Neural Regen. Res. 2020, 15, 1408-1416.

30. Sánchez-Vioque, R.; Santana-Méridas, O.; Polissiou, M.; Vioque, J.; Astraka, K.; Alaiz, M.; Herraiz-Peñalver, D.; Tarantilis, P.A.; Girón-Calle, J. Polyphenol composition and in vitro antiproliferative effect of corm, tepal and leaf from Crocus sativus L. on human colon adenocarcinoma cells (Caco-2). J. Funct. Foods 2016, 24, 18-25. [CrossRef]

31. Wali, A.F.; Pillai, J.R.; Al Dhaheri, Y.; Rehman, M.U.; Shoaib, A.; Sarheed, O.; Jabnoun, S.; Razmpoor, M.; Rasool, S.; Paray, B.A.; Ahmad, P. Crocus sativus L. Extract Containing Polyphenols Modulates Oxidative Stress and Inflammatory Response against Anti-Tuberculosis Drugs-Induced Liver Injury. Plants 2020, 9, 167. [CrossRef]

32. Wali, A.F.; Alchamat, H.A.A.; Hariri, H.K.; Hariri, B.K.; Menezes, G.A.; Zehra, U.; Rehman, M.U.; Ahmad, P. Antioxidant, Antimicrobial, Antidiabetic and Cytotoxic Activity of Crocus sativus L. Petals. Appl. Sci. 2020, 10, 1519. [CrossRef]

33. Hoshyar, R.; Hosseinian, M.; Naghandar, M.R.; Hemmati, M.; Zarban, A.; Amini, Z.; Valavi, M.; Beyki, M.Z.; Mehrpour, O. Anti-dyslipidemic properties of Saffron: Reduction in the associated risks of atherosclerosis and insulin resistance. Iran Red Crescent Med. J. 2016, 18. [CrossRef]

34. Basti, A.A.; Moshiri, E.; Noorbala, A.A.; Jamshidi, A.H.; Abbasi, S.H.; Akhondzadeh, S. Comparison of petal of Crocus sativus L. and fluoxetine in the treatment of depressed outpatients: A pilot double-blind randomized trial. Prog. Neuropsychopharmacol. Biol. Psychiatry 2007, 31, 439-442. [CrossRef]

35. Hosseini, A.; Razavi, B.M.; Hosseinzadeh, H. Saffron (Crocus sativus) petal as a new pharmacological target: A review. Iran. J. Basic Med. Sci. 2018, 21, 1091-1099.

36. Jadouali, S.; Atifi, H.; Bouzoubaa, Z.; Majourhat, K.; Gharby, S.; Achemchem, F.; Elmoslih, A.; Laknifli, A.; Mamouni, R. Chemical characterization, antioxidant and antibacterial activity of Moroccan Crocus sativus L. petals and leaves. J. Mater. Environ. Sci. 2018, 9, 113-118. [CrossRef] 
37. Rahaiee, S.; Ranjbar, M.; Azizi, H.; Govahi, M.; Zare, M. Green synthesis, characterization, and biological activities of saffron leaf extract-mediated zinc oxide nanoparticles: A sustainable approach to reuse an agricultural waste. Appl. Organomet. Chem. 2020, 34, e5705. [CrossRef]

38. Sánchez-Vioque, R.; Rodríguez-Conde, M.; Reina-Urena, J.; Escolano-Tercero, M.; Herraiz-Peñalver, D.; Santana-Méridas, O. In vitro antioxidant and metal chelating properties of corm, tepal and leaf from saffron (Crocus sativus L.). Ind. Crops Prod. 2012, 39, 149-153. [CrossRef]

39. Baba, S.A.; Malik, A.H.; Wani, Z.A.; Mohiuddin, T.; Shah, Z.; Abbas, N.; Ashraf, N. Phytochemical analysis and antioxidant activity of different tissue types of Crocus sativus and oxidative stress alleviating potential of saffron extract in plants, bacteria, and yeast. S. Afr. J. Bot. 2015, 99, 80-87. [CrossRef]

40. Esmaeelian, M.; Jahani, M.; Feizy, J.; Einafshar, S. Effects of Ultrasound-Assisted and Direct Solvent Extraction Methods on the Antioxidant and Antibacterial Properties of Saffron (Crocus sativus L.) Corm Extract. Food Anal. Methods 2020. [CrossRef]

41. Escribano, J.; Rubio, A.; Alvarez-Ortí, M.; Molina, A.; Fernández, J.A. Purification and Characterization of a Mannan-Binding Lectin Specifically Expressed in Corms of Saffron Plant (Crocus sativus L.). J. Agric. Food Chem. 2000, 48, 457-463. [CrossRef]

42. Mohajeri, S.A.; Hedayati, N.; Bemani-Naeini, M. Available saffron formulations and product patents. In Saffron; Elsevier: Amsterdam, The Netherlands, 2020; pp. 493-515.

43. Amin, A.; Hamza, A.; Bajbouj, K.; Ashraf, S.A.; Daoud, S. Saffron: a potential candidate for a novel anti-cancer drug against hepatocellular carcinoma. Hepatology 2011, 54, 857-867. [CrossRef]

44. Ma, L.; Xu, G.B.; Tang, X.; Zhang, C.; Zhao, W.; Wang, J.; Chen, H. Anti-cancer potential of polysaccharide extracted from hawthorn (Crataegus.) on human colon cancer cell line HCT116 via cell cycle arrest and apoptosis. J. Funct. Foods 2020, 64, 103677. [CrossRef]

45. Fatehi, M.; Rashidabady, T.; Fatehi-Hassanabad, Z. Effects of Crocus sativus petals' extract on rat blood pressure and on responses induced by electrical field stimulation in the rat isolated vas deferens and guinea-pig ileum. J. Ethnopharmacol. 2003, 84, 199-203. [CrossRef]

46. Ahmad Nazri, K.A.; Fauzi, N.M.; Buang, F.; Mohd Saad, Q.H.; Husain, K.; Jantan, I.; Jubri, Z. Gynura procumbens Standardised Extract Reduces Cholesterol Levels and Modulates Oxidative Status in Postmenopausal Rats Fed with Cholesterol Diet Enriched with Repeatedly Heated Palm Oil. Evid. Based Complement. Altern. Med. 2019, 2019, 1-15. [CrossRef] [PubMed]

47. Akbari-Fakhrabadi, M.; Najafi, M.; Mortazavian, S.; Rasouli, M.; Memari, A.H.; Shidfar, F. Effect of saffron (Crocus sativus L.) and endurance training on mitochondrial biogenesis, endurance capacity, inflammation, antioxidant, and metabolic biomarkers in Wistar rats. J. Food Biochem. 2019, 43, 1-10. [CrossRef]

48. Hosseinzadeh, H.; Younesi, H.M. Antinociceptive and anti-inflammatory effects of Crocus sativus L. stigma and petal extracts in mice. BMC Pharmacol. 2002, 2,7.

49. Li, F.; Huo, J.; Zhuang, Y.; Xiao, H.; Wang, W.; Huang, L. Anti-nociceptive and anti-inflammatory effects of the ethanol extract of Arenga pinnata (Wurmb) Merr. fruit. J. Ethnopharmacol. 2020, 248, 112349. [CrossRef]

50. Iranshahi, M.; Khoshangosht, M.; Mohammadkhani, Z.; Karimi, G. Protective effects of aqueous and ethanolic extracts of saffron stigma and petal on liver toxicity induced by carbon tetrachloride in mice. Pharmacologyonline 2011, 1, 203-212.

51. Escribano, J.; Alonso, G.L.; Coca-Prados, M.; Fernández, J.A. Crocin, safranal and picrocrocin from saffron (Crocus sativus L.) inhibit the growth of human cancer cells in vitro. Cancer Lett. 1996, 100, 23-30. [CrossRef]

52. Hosseinzadeh, H.; Shariaty, V.M.; Sameni, A. Acute and sub-acute toxicity of crocin, a constituent of Crocus sativus L. (Saffron), in mice and rats. Pharmacologyonline 2010, 2, 943-951.

53. González-Cano, R.; Montilla-García, Á.; Ruiz-Cantero, M.C.; Bravo-Caparrós, I.; Tejada, M.Á.; Nieto, F.R.; Cobos, E.J. The search for translational pain outcomes to refine analgesic development: where did we come from and where are we going? Neurosci. Biobehav. Rev. 2020, 113, 238-261. [CrossRef]

54. Deuis, J.R.; Dvorakova, L.S.; Vetter, I. Methods used to evaluate pain behaviors in rodents. Front. Mol. Neurosci. 2017, 10, 284. [CrossRef] [PubMed]

55. Yang, D.J.; Lin, J.T.; Chen, Y.C.; Liu, S.C.; Lu, F.J.; Chang, T.J.; Wang, M.; Lin, H.W.; Chang, Y.Y. Suppressive effect of carotenoid extract of Dunaliella salina alga on production of LPS-stimulated pro-inflammatory mediators in RAW264. 7 cells via NF-kB and JNK inactivation. J. Funct. Foods 2013, 5, 607-615. [CrossRef]

56. Tamaddonfard, E.; Farshid, A.A.; Hosseini, L. Crocin alleviates the local paw edema induced by histamine in rats. Avicenna J. Phytomed. 2012, 2, 97-104. [PubMed] 
57. Gupta, A.K.; Parasar, D.; Sagar, A.; Choudhary, V.; Chopra, B.S.; Garg, R.; Khatri, N. Analgesic and anti-inflammatory properties of gelsolin in acetic acid induced writhing, tail immersion and carrageenan induced paw edema in mice. PLOS ONE 2015, 10, e0135558. [CrossRef] [PubMed]

58. Masresha, B.; Makonnen, E.; Debella, A. In vivo anti-inflammatory activities of Ocimum suave in mice. J. Ethnopharmacol. 2012, 142, 201-205. [CrossRef] [PubMed]

59. Hossain, K.H.; Rahman, M.A.; Taher, M.; Tangpong, J.; Hajjar, D.; Alelwani, W.; Makki, A.A.; Ali Reza, A.S.M. Hot methanol extract of Leea macrophylla (Roxb.) manages chemical-induced inflammation in rodent model. J. King Saud Univ. Sci. 2020, 32, 2892-2899. [CrossRef]

60. Pandey, K.D.; Singh, Y.; Khatri, N.; Singh, N. Phytochemical Screening and Anti-inflammatory activity of Murraya koenigii \& Ficus lacor roots in Carrageenan, Histamine and Serotonin induced paw edema in albino Wistar rats. Int. J. Rec. Adv. Sci. Technol. 2020, 6, 1-12.

61. Aoki, T.; Narumiya, S. Prostaglandins in Chronic Inflammation. In Chronic Inflammation: Mechanisms and Regulation; Miyasaka, M., Takatsu, K., Eds.; Springer: Tokyo, Japan, 2016; pp. 3-17.

62. Arulmozhi, D.; Veeranjaneyulu, A.; Bodhankar, S.; Arora, S. Pharmacological investigations of Sapindus trifoliatus in various in vitro and in vivo models of inflammation. Indian J. Pharmacol. 2005, 37, 96-102.

63. Yang, Y.; Wei, Z.; Teichmann, A.T.; Wieland, F.H.; Wang, A.; Lei, X.; Zhu, Y.; Yin, J.; Fan, T.; Zhou, L.; Wang, C.; Chen, L. Development of a novel nitric oxide (NO) production inhibitor with potential therapeutic effect on chronic inflammation. Eur. J. Med. Chem. 2020, 193, 112216. [CrossRef]

64. Arbabian, S.; Izadi, H.; Ghoshouni, H.; Shams, J.; Zardouz, H.; Kamalinezhad, M.; Sahraei, H.; Nourouzzadeh, A. Effect of water extract of saffron (Crocus sativus) on chronic phase of formaline test in female mice. Kowsar Med. J. 2009, 14, 11-18.

65. Kumar, V.; Bhat, Z.A.; Kumar, D.; Khan, N.; Chashoo, I.; Shah, M. Evaluation of anti-inflammatory potential of petal extracts of Crocus sativus "cashmerianus". Int. J. Phytopharm. 2012, 3, 27-31.

66. Kong, L.; Luo, C.; Li, X.; Zhou, Y.; He, H. The anti-inflammatory effect of kaempferol on early atherosclerosis in high cholesterol fed rabbits. Lipids Health Dis. 2013, 12, 115. [CrossRef] [PubMed]

67. Ogedegbe, H.O. An overview of hemostasis. Lab. Med. 2002, 33, 948-953. [CrossRef]

68. Scarano, A.; Murmura, G.; di Cerbo, A.; Palmieri, B.; Pinchi, V.; Mavriqi, L.; Varvara, G. Anti-Hemorrhagic Agents in Oral and Dental Practice: An Update. Int. J. Immunopathol. Pharmacol. 2013, 26, 847-854. [CrossRef] [PubMed]

69. Kurt, M.; Onal, I.; Akdogan, M.; Kekilli, M.; Arhan, M.; Sayilir, A.; Oztas, E.; Haznedaroglu, I. Ankaferd Blood Stopper for controlling gastrointestinal bleeding due to distinct benign lesions refractory to conventional antihemorrhagic measures. Can. J. Gastroenterol. 2010, 24, 380-384. [CrossRef] [PubMed]

70. Ismail, H.; Rasheed, A.; Haq, I.U.; Jafri, L.; Ullah, N.; Dilshad, E.; Sajid, M.; Mirza, B. Five indigenous plants of Pakistan with Antinociceptive, anti-inflammatory, antidepressant, and anticoagulant properties in Sprague Dawley rats. Evid. Based Complement. Altern. Med. 2017, 2017, 1-10. [CrossRef]

71. Liakopoulou-Kyriakides, M.; Sinakos, Z.; Kyriakidis, D. A high molecular weight platelet aggregating factor in Crocus sativus. Plant Sci. 1985, 40,117-120. [CrossRef]

72. Liakopoulou-Kyriakides, M.; Skubas, A. Characterization of the platelet aggregation inducer and inhibitor isolated from Crocus sativus. Biochem. Int. 1990, 22, 103-110.

73. Ma, S.; Liu, B.; Zhou, S.; Xu, X.; Yang, Q.; Zhou, J. Pharmacological studies of glycosides of saffron Crocus (Crocus sativus). II. Effects on blood coagulation, platelet aggregation and thromobosis. Chin. Trad. Herbal Drugs 1999, 30, 196-198.

74. Yang, Y.; Qian, Z. Effect of crocetin on platelet aggregation in rats. Chin. J. Nat. Med. 2007, 5, 374-378.

75. Yang, L.; Qian, Z.; Yang, Y.; Sheng, L.; Ji, H.; Zhou, C.; Kazi, H.A. Involvement of Ca2+ in the Inhibition by Crocetin of Platelet Activity and Thrombosis Formation. J. Agric. Food Chem. 2008, 56, 9429-9433. [CrossRef] [PubMed]

76. Modaghegh, M.H.; Shahabian, M.; Esmaeili, H.A.; Rajbai, O.; Hosseinzadeh, H. Safety evaluation of saffron (Crocus sativus) tablets in healthy volunteers. Phytomedicine 2008, 15, 1032-1037. [CrossRef] [PubMed]

77. Ayatollahi, H.; Javan, A.O.; Khajedaluee, M.; Shahroodian, M.; Hosseinzadeh, H. Effect of Crocus sativus L.(saffron) on coagulation and anticoagulation systems in healthy volunteers. Phytother. Res. 2014, 28, 539-543. [CrossRef] 
78. Haroz, E.E.; Ritchey, M.; Bass, J.K.; Kohrt, B.A.; Augustinavicius, J.; Michalopoulos, L.; Burkey, M.D.; Bolton, P. How is depression experienced around the world? A systematic review of qualitative literature. Soc. Sci. Med. 2017, 183, 151-162. [CrossRef] [PubMed]

79. Khawam, E.; Laurencic, G.; Malone, D. Side effects of antidepressants: an overview. Cleve. Clin. J. Med. 2006, 73, 351. [CrossRef]

80. Wang, Y.; Han, T.; Zhu, Y.; Zheng, C.J.; Ming, Q.L.; Rahman, K.; Qin, L.P. Antidepressant properties of bioactive fractions from the extract of Crocus sativus L. J. Nat. Med. 2009, 64, 24. [CrossRef]

81. Hausenblas, H.A.; Saha, D.; Dubyak, P.J.; Anton, S.D. Saffron (Crocus sativus L.) and major depressive disorder: a meta-analysis of randomized clinical trials. J. Integr. Med. 2013, 11, 377-383. [CrossRef]

82. Petit-Demouliere, B.; Chenu, F.; Bourin, M. Forced swimming test in mice: a review of antidepressant activity. Psychopharmacology 2005, 177, 245-255. [CrossRef]

83. Kayani, W.K.; Dilshad, E.; Ahmed, T.; Ismail, H.; Mirza, B. Evaluation of Ajuga bracteosa for antioxidant, anti-inflammatory, analgesic, antidepressant and anticoagulant activities. BMC Complement. Altern. Med. 2016, 16, 375. [CrossRef]

84. Ismail, H.; Mirza, B. Evaluation of analgesic, anti-inflammatory, anti-depressant and anti-coagulant properties of Lactuca sativa (CV. Grand Rapids) plant tissues and cell suspension in rats. BMC Complement. Altern. Med. 2015, 15, 199. [CrossRef]

85. Hosseinzadeh, H.; Motamedshariaty, V.; Hadizadeh, F. Antidepressant effect of kaempferol, a constituent of saffron (Crocus sativus) petal, in mice and rats. Pharmacologyonline 2007, 2, 367-370.

86. Eddy, N.B.; Leimbach, D. Synthetic analgesics. II. Dithienylbutenyl- and dithienylbutylamines. J. Pharmacol. Exp. Ther. 1953, 107, 385-393.

87. Winter, C.A.; Risley, E.A.; Nuss, G.W. Carrageenin-induced edema in hind paw of the rat as an assay for antiinflammatory drugs. Exp. Biol. Med. 1962, 111, 544-547. [CrossRef] [PubMed]

88. Porsolt, R.D.; Bertin, A.; Blavet, N.; Deniel, M.; Jalfre, M. Immobility induced by forced swimming in rats: Effects of agents which modify central catecholamine and serotonin activity. Eur. J. Pharmacol. 1979, 57, 201-210. [CrossRef]

Publisher's Note: MDPI stays neutral with regard to jurisdictional claims in published maps and institutional affiliations.

(C) 2020 by the authors. Licensee MDPI, Basel, Switzerland. This article is an open access article distributed under the terms and conditions of the Creative Commons Attribution (CC BY) license (http://creativecommons.org/licenses/by/4.0/). 